\title{
An Empirical Study on the Curriculum Construction of Business English for International Trade Based on the Case of GDUFS
}

\author{
Zhu Wenzhong ${ }^{1} \&$ Zhang Cheng ${ }^{2}$ \\ ${ }^{1}$ Professor of SEIB, Guangdong University of Foreign Studies, China \\ ${ }^{2}$ Graduate student, School of English for International Business, Guangdong University of Foreign Studies, \\ China \\ Correspondence: Zhu Wenzhong, Guangdong University of Foreign Studies, Guangzhou 510410, China. E-mail: \\ wenzhong8988@sina.com
}

Received: January 17, 2013 Accepted: January 24, 2013 Online Published: March 10, 2013

doi:10.5539/elt.v6n4p19 URL: http://dx.doi.org/10.5539/elt.v6n4p19

This paper is sponsored by the 2012 Project of Postgraduate Teaching Reform (12GWYJSJG -10) sponsored by Guangdong University of Foreign Studies and the 2012 Project of Higher Education Teaching Quality and Reform (222-GK120063) sponsored by Guangdong Provincial Department of Education.

\begin{abstract}
Business English education concern is of great significance. Business English for International Trade in Guangdong University of Foreign Studies (GDUFS) is widely acclaimed, and it is also a popular major. GDUFS has adopted the slogan "Learn from East and West, moral integrity and direct behavior". It is a famous cradle of learning, where complex and capable persons are educated. Through review and reflection into the findings of the practice of business English in GDUFS and other instructions, this paper is aimed at analyzing the situation of the present curriculum, identifying existing problems such as the misbalance between the English courses and Business courses based on the theory of Needs Analysis, and then make some suggestions to increase the percentage of the Business courses and Business practices. In this way, this paper can serve as a reference for the curriculum construction of Business English for International trade in GDUFS.
\end{abstract}

Keywords: Needs Analysis, GDUFS, Business English, curriculum construction

\section{Introduction}

\subsection{Background of the Study}

Business English education concern is of great significance. The world we live in today is dramatically different than it was just a decade ago. We have witnessed significant advances in technology, global trade, and changes in the labor market. If China is going to continue to lead the world in growth, it must begin to move from being the world's factory to being a leader in innovative technology and services. In order to adapt to this change, Chinese companies need to collect a large group of talents who can master foreign language and doing foreign trade, so business English education is very essential for the development of the whole country.

\subsubsection{The History and Development of Business English in China}

Business English in China has experienced three stages development as follows:

Stage 1: 1950s 1980s

The teaching of Business English in the People's Republic of China dates back to the early 1950s, when the College for Senior Cadres of Commerce, the first college of its kind specializing in training personnel for foreign trade, was established in Beijing. The college admitted students to it's "English Translation" program with the go of producing translators and interpreters in the field of foreign trade. To this end, students were required to master a foreign language oriented to foreign trade, learn techniques of foreign trade, and become familiar with China's trade policies. The three successors of the college, Beijing College of Foreign Trade, Beijing Institute of Foreign Trade, and the University of International Business and Economics, inherited this tradition. They all admitted English majors whose English courses were oriented to foreign trade despite the gradual change of the names of the programs, for example, "English Translation for Foreign Trade" in the 1950s and 60s, "English for 
Foreign Trade" in the 1970s and 1980s, "English for Specific Purposes (international trade)" in the early 1990s, "English (economics and trade)" in the late 1990s, and "English" from 2000 up to the present.

Stage 2: 1980s 1990s

Since the early 1980s when China opened up to the outside and moved towards a market economy, students of Business English found themselves having to learn not only the language but also the way of doing business. As a result, course offerings multiplied. In addition to the three traditional courses, such content-based courses as marketing, management, and international co-operation were also offered in English. The intuition was that students would pick up the language while being immersed in the English-mediated instruction. Course materials with fancy titles multiplied.

The 1990s witnessed a boom in Business English teaching in China. The number of colleges and universities offering Business English programs increased significantly. An event worth noting was the accreditation of Business English by the Ministry of Education as one of the major ways of producing fuhexingrencai (multi-talents) apart from the literature and linguistics-oriented English teaching in departments of English at different universities.

Stage 3: 1990s $\sim$ present

Over the last decade or so, there have been persistent efforts to upgrade the curriculum for students of Business English in China. Wang and $\mathrm{Xu}$ proposed a two-stage curriculum which attached importance to the learning of subject knowledge as well as language skills. Chen called for a more systematic Business English curriculum, arguing that subject knowledge and language skills could be incorporated. Partly in response to such input, the curriculum for English majors admitted to the University of International Business and Economics in 2000 included a range of courses in business subjects; for example, Western economics, business ethics, and business law. However, the business courses and language skills courses were rather independent and autonomous modules in the curriculum. In addition, the language skills courses generally excluded the concern with the disciplinary context and inadequately addressed the professional con- text, sign that a coherent theoretical framework for Business English was lacking.

\subsubsection{The History and Development of Business English for International Trade Major in GDUFS}

Now, business English major is very popular in many universities. School of English for International Business in GDUFS was established in 2001 which consist of two professional directions: international trade and international finance. Its way of education is to combine the language education and professional knowledge, cultivating complex and capable talents who master the basic principle and skills of international trade and international finance so that they can not only have the preliminary scientific research ability but also the ability to work in the apartment related to international trade, international exchange and international finance.

In the four years of undergraduate education, the first two years stage is to cultivate students' solid language ability, ensuring a solid English language foundation; In the later two years, the focus turn to the study of professional courses, teaching courses of international trade and financial knowledge in English, and teaching basic knowledge and skills of computer. The department of English for international trade pays special attention to cultivate students' cross-cultural communication skills, independent analysis ability and the ability to solve problems, and help students get all-round development in various aspects, such as English listening, speaking, reading, writing and translating. So how to help students to gain special competitiveness among thousands of competitors has become an outstanding issue for GDUFS. Even though business English has many existing outcomes on curriculum construction, it still needs to be improved so that it can meet the student's needs and wants better and they can have a better study plan and career plan.

\subsubsection{The Current Situation of Curriculum Construction}

The student majoring in English for International Trade in GDUFS are taking the courses including macroeconomics, microeconomics, introduction of contemporary business, international trade in practices, international settlement and so on. It is generally divided into two parts: English language knowledge and Business knowledge. The chart below will show all the courses and their relative class hours (1 presents one term; 2 presents two terms; etc) 
Table 1. The courses and their relative class hours of BE

\begin{tabular}{ll}
\hline English Language & Business Professional \\
\hline Comprehensive English2 & Business Communication(listening)2 \\
English listening2 & Business English2 \\
English Writing4 & Business Meeting and telephoneing2 \\
English and American Literature1 & Contemporary Business2 \\
English society and culture1 & Microeconomics1 \\
Cross-cultural communication1 & Macroeconomics1 \\
English translation2 & E-commerce1 \\
English interpretation2 & Accounting principle2 \\
Business English translation1 & International trade practices2 \\
linguistics1 & International settlement1 \\
Stylistics1 & International finance2 \\
Advanced English 3 & International Marketing1 \\
\hline
\end{tabular}

\subsection{Purpose and Significance of the Study}

The purpose of the study is to provide some useful guide for the teaching in GDUFS, and make the curricular more suitable for the students' personal development and meet the society better.

Based on the theory of needs analysis, this paper conducted over 100 effective questionnaires for three grades GDUFS students majoring in English for International Trade. These three grades are the junior, the senior and the graduates.

This paper offers good advices for school to further develop its curricular construction. It is of great importance for students, school and the whole society. It can enrich the effectiveness of using the precious college learning time; improve school's teaching level and competitiveness; deliver more international trade talents for the society.

\section{Literature Review}

\subsection{The Concept of Needs Analysis}

Needs analysis (also known as needs assessment) has a vital role in the process of designing and carrying out any language course, whether it is English for Specific Purposes (ESP) or general English course, and its centrality has been acknowledged by several scholars and authors.

The word "assess" comes from the Latin term "assidere," which means to "sit beside." Process-minded and participatory-oriented adult educators "sit beside" learners to learn about their proficiencies and backgrounds, educational goals, and expected outcomes, immersing themselves in the lives and views of their students (Auerbach, 1994). Berwick (1989: 52) offers a simplified conventional definition of need as the 'discrepancy between a current state of affairs and a desired future state'. If this controversy is meant to reveal anything, it should be the ambiguity loaded within the phrase "needs assessment".

\subsection{The Importance of Implementing A Needs Analysis}

Learners and teachers may have different needs. This why needs analysts should be cautious in collecting information from various sources due to the multiplicity and diversity of the views on prerequisites for an ESP. Hutchinson and Waters (1993) hold that the relationship between necessities as perceived by a sponsor or an ESP teacher, and what learners want or feel can be at extreme poles. They suggest that learners' perceived wants and wishes should be considered carefully, and due to objective and subjective reality of needs, each learning situation should be considered uniquely and systematically.

Bearing in mind a wide range of needs due to the influence of different social and cultural factors on student's learning (Peck, 1991), a needs analysis is considered as a prerequisite in any course design (Richterich and Chancerel, 1987). According to Knox (1997: 56), needs assessment enables researchers to justify their assumptions as to whether or not potential educational needs are sound, to design a program in terms of topics, materials so as to be responsive to the needs of participants.

A needs assessment serves a number of purposes: it aids administrators, teachers, and tutors with learner 
placement, developing materials, curricula, skills assessments, teaching approaches, and teacher training; it assures a flexible, responsive curriculum rather than a fixed and linear curriculum determined ahead of time by instructors; it provides information to the instructor about what the learner brings to the course (if done at the beginning), what has been accomplished (if done during the course), and what the learner wants and needs to know next. When learners know that educators understand and want to address specific needs and interests, the former are motivated to continue learning.

\subsection{Approaches to Needs Analysis}

First, a careful needs analysis should involve "Present Situation Analysis" (PSA) and "Target Situation Analysis" (TSA). PSA aims at finding out the students' English proficiency level and their existing language requirements at the beginning of a language program, whereas learners' language requirements regarding the target situation are identified through TSA (Robinson, 1991). Bloor (1984) defines the former type of analysis as a learner-centered needs analysis, and the latter one as a target-centered analysis. Bloor emphasizes that operation of both analyses during a term is certainly desirable. Robinson (1991) also holds that TSA and PSA are complementary and form an efficient form of needs analysis. Jordan (1997) proposes a "tri-chotomy" of needs analysis which comprises: 1) deficiency analysis, 2) strategy analysis, 3) and means analysis.

Furthermore, various analyses and approaches to needs assessment were put forward: such as the analytic view of needs analysis which examines expert opinion, and the diagnostic approach which examines the learner's needs to be used in social services (Berwick, 1989); the discrepancy analysis which attempts to examine what people know and what they ought to know, and democratic approach which is based on learner points of view (Stufflebeam et al, 1985, quoted in Berwick, 1989).

\subsection{Techniques Used in Needs Analysis}

Several basic Needs Assessment techniques include: direct observation, questionnaires, consultation with persons in key positions and/or with specific knowledge, review of relevant literature, interviews, focus groups, tests, class discussions, records \& report studies, work samples and so on.

To sum up, Needs Analysis is the best and most suitable way of analyzing the rationality of the curriculum construction for Business English.

\section{Empirical Study and Corresponding Suggestions}

This part will show a questionnaire analysis, which is designed according to the components of Needs Analysis mentioned above.

\subsection{The Background of the Questionnaire}

\subsubsection{Subjects}

In order to conduct the study, I chose 100 students from three different grades in the School of English for International Business in GDUFS whose major are English for International Trade. These students are junior students, senior students and the graduates. The juniors have already learned most of the major courses and taken important internships such as working for Canton Fair at least once, so they are very familiar with the courses and have a general feeling about the rationality of the curriculum design. The seniors are leaving school and experiencing the challenge and selection from the society, and they have all finished the course and can give better feedback of the fitness between the course and the employment requirements. The graduates who have already got jobs and worked for a years can tell much more practically about the advantages and disadvantages of the course they had in university.

\subsubsection{Objectives}

The objective of this investigation is to look deep into students' opinions and views about present curriculum, whose major is English for International Trade (EFIT) in Guangdong University of foreign studies (GDUFS).

\subsubsection{The content of the Questionnaire}

The content of the questionnaire was set according to the Need Analysis, which consist of thirteen questions in total. It collects answers about the aim of majoring in English for International Trade (EFIT), the expectation of the course, the degree of satisfaction and the suggestions about the course design and the teaching style and so on. I collected 100 valid responses on the internet and interviewed several alumni with years of working experience. 


\subsection{The Analysis of the Questionnaire}

\subsubsection{Satisfaction Analysis}

Q1: Are you satisfied with EFIT courses?

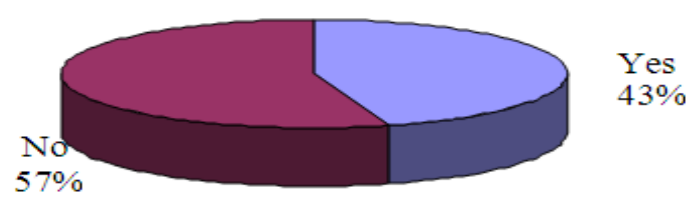

Figure 1.

Students' satisfaction can directly demonstrate whether the program is successful and imply whether it will succeed in the future. A high rate of satisfaction not only boosts students' and teachers' confidence but also attracts more potential talents. When asked "Are you satisfied with the curriculum layout for EFIT majors?" 43 people choose "Yes", accounting for $43 \%$ of all the respondents, while 57 students say "No", expressing their dissatisfaction.

More than half of the students are not content with what they have learned in the four-year study. The reasons range from inappropriate timing and proportion of the curricula to unattractive teaching methods and the inefficient assessment. Many students complain that they have spent too much time learning the useless and outdated information. Some interviewees worry that they cannot meet the need of the practical work in the future because the internship is not stressed by schools and themselves. The statistics showed great room for improvement in the future.

\section{Q2: What dissatisfy you?}

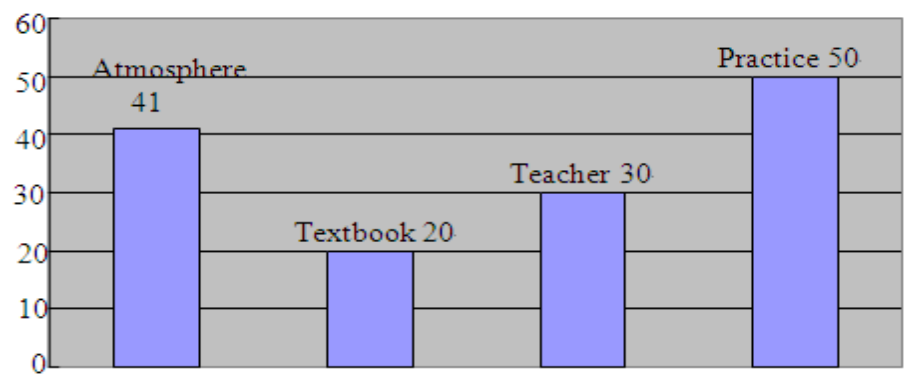

Figure 2 .

People have different answers about what should be improved in this major. 50 students state that we lack of the opportunity to apply the professional knowledge to work outside the college; 41 students want a good learning atmosphere; 30 students think their teachers should be professional in respective fields but also can use English accurately and fluently in the class; 20 respondents believe a series of compatible textbooks for Chinese students will improve their school performance. Among those elements causing dissatisfaction, issues like learning environment and practice opportunities make up more than $60 \%$, which indicates that software such as environment and opportunities play a essential role in EFIT learning. With the perfection of the schools' hardware, students' attention has shifted to high level demand of chances and atmosphere. This group of numbers again reminds us that EFIT is learnt for practical use. Only the classic cases and theories from book are not enough. EFIT departments should create every opportunity to provide students with the authentic working environment and the real difficulties in the career, so that graduates will quickly be adapted to the demanding work.

EFIT majors seem more frivolous in learning and superficial in understanding. This is not all the fault of the 
students, who are influenced by consumerism and Mormonism. It might be caused by the characteristics of the business activities, which is like a game that is full of challenges, risks and changes. Challenges and risks require people to become daring in front of the opportunities and those who make a great fortune through speculation and even some illegitimate behavior such as bribery and forgery are often glamorized by the press and worshiped in this circle. Too many changes make people lack of vision and think or act for a short term benefit.

A good learning atmosphere is the result of the joint efforts of students and teachers. Students need to bear in mind that basic skills are the key to success and it is also fundamental for teachers to prioritize the moral education and business ethics. Good performance resulted from long term efforts might bring about the social reputation and draw the attention of potential candidates with business talents in later enrollment, which could in turn strengthen the atmosphere and outcome.

\section{Q3: Future development of EFIT major?}

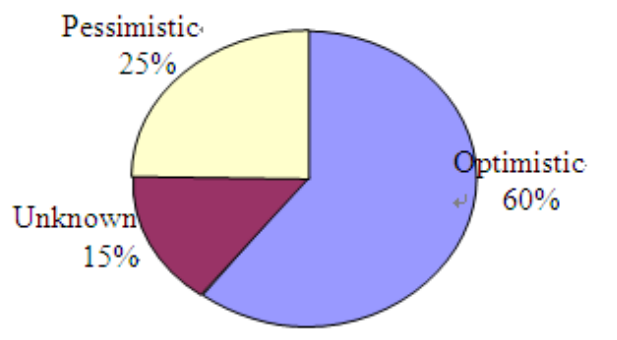

Figure 3.

To the future development of the discipline, people hold various statements with various reasons to support themselves. It is obvious that students are optimist about the future of BE. $60 \%$ of them hold that pragmatism is the global tendency and an increasing number of high school students will apply for this program and as a result more colleges will open the similar courses. A quarter of the surveyed don't think the discipline will sustain any more because of its unclear characteristics and advantages. The remaining 15\% cannot find the difference from English language majors and economics majors. They are not certain about its future development.

This outcome is not surprising, because after the entry into WTO, China's economic growth has entered an unprecedented period. The whole world needs China, and China's development cannot be separated from the world. More and more young people choose BE as major in order to promote their own living standard and make contributions to a harmoniously prosperous world.

This figure also shows that the increasing demand raises a challenge for the disciplinary development. To distinguish BE from ordinary English department or institute of economics and trade, it needs to attract qualified teachers and invest more in researching. Some students call for high standard textbooks jointly compiled by colleges nationwide. The only solution is to promote the cooperation of students and teachers and to strengthen the exchange of information. Only in this way BE could be strengthened as an independent discipline.

\subsubsection{Motivation Analysis}

Teachers could improve their lecturing methods and adjust the difficulties accordingly, if they know students' purpose of choosing EFIT as their major. 23 of the respondents say it is because they like English and only 10 express their eagerness to be a businessperson. 52 of the surveyed choose it in that the compound discipline will be an advantage to find a good job. 15 students are forced to major in EFIT by their parents or other external reasons. Most graduates are optimistic about the future of themselves because they think the four years' study has helped nurture them a compound and professional man and EFIT graduates are preferred by enterprises. EFIT is a market-oriented and employment-oriented major, so finding a good job is the focus of students. To the question of what occupation do you think is most suitable for you in the future. $16 \%$ of graduates want to take up some career related to the English language, such as teachers, editors or interpreters; $45 \%$ of students would like to join the business circle; $39 \%$ of people are willing to be neither of them. Those whose millionaire dreams are based on EFIT courses are apt to believe the employment-oriented disciplinary advantage. From the beginning, they have a very clear objective and the psychological hints that they will benefit from the class on the path to the business circle are constantly strengthened during the learning phase. They can take a positive stance in the 
competition and tend to be more successful than other students. On the contrary, those who simply like English or who are compelled to learn are less possible to believe it is easy to find a job. This group of students tends to be in lack of a correct self-orientation and doubt the booklore.

Teachers need to inspire students and encourage them to observe and think from an economic perspective in daily life. In this way, students might understand the essence of economics and can quickly use in reality. For those really dissatisfied persons, schools are responsible to create opportunities to transfer them to other departments, although it is tough decision recently in China. Interest is the best teacher in language learning, and education should focus on the all-round development of students and provide more alternative for them.

After four years' study, more students would like to engage in the work of language, which demonstrates that language learning is the core of EFIT curricula at present and the successful teaching methods boost students' confidence. More students haven't made up their minds what to do or choose other occupations like civil servants; this is a warning signal that the career plan and advice from experts about employment are significant for EFIT majors.

3.2.3 Analysis of the Number, Kind and Proportion of the Core Courses

\section{Q8: Which courses should be emphasized?}

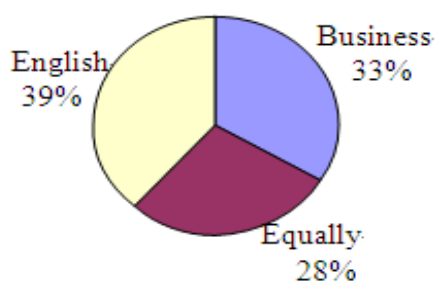

Figure 4.

Whether an EFIT program is successful or not relies mostly on its courses. Good courses of right proportion are crucial to motivate students' interest and help them carry on with their study. A correct arrangement of different courses in different semesters is important because it ensures that students can start from the easiest courses and then up to the advanced courses. When asked what they think are the most useful course, most students choose courses involving basic English skills such as listening, speaking, reading, writing, translation and interpreting. This shows English skills still remain at the core of the ESP language learning. Equally many students prefer practical courses concerning economics and business: marketing, basic accounting, e-commerce, international trade practice, international finance, international settlement, international economic law, which demonstrates the desire to grasp some expertise in the rapid pace of modern life. Moreover, business and economic theories like the principle of microeconomics and macroeconomics, an introduction to contemporary business as well as such cross-disciplinary subjects as business communication, business negotiation, business translation and business culture are popular among learners for they have realized that the theories form sound basis for the development of skills. Students are least interested in humanities and mathematics, because they think they are boring and useless.

It is essential to keep a balance between English and Business courses. More than two-thirds of the surveyed think English should be taught as the major and business subjects are only the minor, since they believe college period is the golden time to grasp a language while they can learn business skills during their future work.

We can infer from the above questions that students want to find an equilibrium point between English courses and business courses, because the difference of preference is not considerable. They prefer practical courses that could be directly converted into social and economic benefits. This phenomenon may be easily explained by the rapid pace of our society and the overwhelming of the pragmatism. The English courses in SEIB of GDUFS are now twice as many as the business courses. It is because the university confers a bachelor's degree of arts in English language and culture. After the occurrence of the bachelor's degree of arts in business English, SEIB should increase its business courses in order to distinguish from its previous form. According to the various interest and levels of the students, it is wise of the school leaders to open more optional courses and reduce the compulsory subjects. By doing so, students with advanced English level could be exempted from certain courses 
and go for more difficult ones, or they can spend more time specializing in business courses.

There appeared a trend that people tend to ignore such basic subjects as humanities and mathematics. It has raised some controversy among experts, because humanities provide truth and advice along with the whole lifetime and mathematics helps to train people's logic and nurture a correct thinking pattern in face of economic problems. It should be noted that mathematics is also a compulsory subject tested in the post-graduate entrance examination if one want further study in the field of economics and management.

\subsubsection{The Language Analysis}

\subsubsection{Language Selection in Giving Lectures}

Since this discipline is EFIT, students expect to learn authentic English at the same time of gaining professional knowledge. English is by all means the first choice of language. Owing to the unique nature of this cross-culture discipline, students might confront many difficulties in understanding the text, so they need explanation in their mother tongue. A common case is that the students know every word in the text, but they have no idea what the author is talking about or they cannot find a correct word to express what they recall in mind. Under such circumstances, bilingual environment is more practical and efficient, because students can get direct help from teachers and save much time guessing the different possibilities.

Actually in China, most English teacher are more comfortable with bilingual classroom, for they are able to quickly explain the language points and get themselves understood. The sole English environment is demanding for a China's teacher giving EFIT. Even if they have a vocabulary large enough, they have to take the feasibility into consideration. As to the textbooks, the original English textbooks are popular because they are compiled by foreigners and represent the latest information and knowledge systems. The major disadvantage of the original books is that they are expensive, and with the perfection of China's protection of the intellectual property rights, it will be illegal to photocopy the whole book without the permission of the author. Bilingual textbooks are well-received in that it can quickly solve all the language difficulties and can be used for self-study. The translation part also provides good resources as the material for the business translation learners. Chinese students had better use Chinese books as supplementary materials, for they read rapid and easy. They are also favorable to broaden the horizon and deepen the understanding.

\subsubsection{The Analysis of the Need of Teachers}

Q11: What kind of teachers do you prefer?

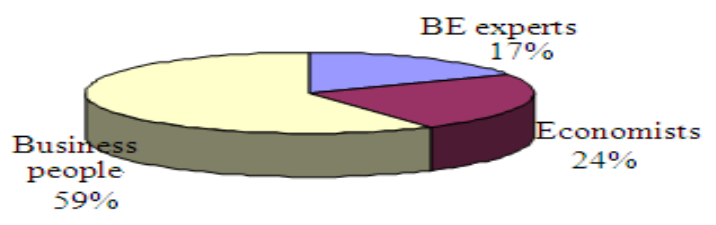

Figure 5 .

Teachers play a very important role in the EFIT teaching, because it is a compound discipline and the requirement is very demanding. Teachers can smoothly link the students and the textbook knowledge as well as enrich students' language competence in terms of vocabulary, grammar, sentence patterns and stylistics. Ironically, students of EFIT don't want EFIT specialists to be their teachers. There are two reasons: one is that specialists are often regarded as boring, less flexible and hard to understand, but students like experienced teachers; the other is EFIT is underdeveloped in domestic academia, and the specialists are in a dilemma that they are not competitive in gaining professional title under such academic systems. These two reasons just account for why teachers who were once in business circle are popular. Experience is the most valuable part of the teachers. As for the scholars, they win the reputation and the support through their authority in their own fields. The result tells us that it is also important to strengthen the English education in all the disciplines. Compared with memorizing vocabulary, it is difficult to catch on the essence of some disciplines. The construction of teaching staff is crucial and arduous for universities in that teachers play a core role in imparting knowledge to students. Experienced and qualified teachers are treasure of the schools and how to make best of these teachers in teaching and researching has become the key issue in the development of the discipline. 


\subsubsection{Means Analysis}

\subsubsection{The Forms of Class}

Students would like to take an equal stance in the class activities, so they don't want teachers to lecture all the time. The characteristics of the BE decide that the class should full of exchange of viewpoints, communication, challenges and discussion. The form of case study first initiated in Harvard University is suitable for BE teaching and learning. Students can learn the real experience from the real cases and get a sense of authenticity. Teamwork is useful to help students to find a correct position in the collective and make sure their respective roles. Through the presentation at the final stage, students can retrospect what they have learned from the process of analysis and improve their expression ability. With the perfection of hardware, multimedia is always used in the presentation.

Besides what is mentioned above, most people want to learn from the practice, for they believe the real working environment and similar challenges are the drive force to learn. Working with experienced colleagues, new-comers can learn quickly and effectively.

\subsubsection{The Means of Practice}

Take the School of English for International Business (SEIB) of Guangdong University of Foreign Studies as example, all the students are appointed to work for the China Import and Export Commodities Fair or Canton Fair in their third year. Most of them spend the month in the registration offices and issue the admission cards for foreigners. Many students complain that they have learnt nothing from the fair, because the registration doesn't need too much expertise. They want to work in the exhibition hall to learn and communicate directly with foreign clients and Chinese enterprises. They want to apply the booklore into practice, so the companies engaging trade, finance and legal service are their best choice.

To those who want to be teachers or interpreters, it is sensible to select schools and translation firms for internship. They can scrutinize their language skills and correct the flaws with the help of experts and constant exercise. Few people would work for government of non-governmental organizations because they seldom show the characteristics of the discipline.

\subsection{Summary of the Questionnaire}

According to the analysis of the questionnaire, it should be pointed out that students have to adapt themselves to the compound discipline and are always in pursuit of being versatile. Teachers need to constantly update their knowledge system and keep a balance between teaching and researching. Schools should provide preferential conditions for the new disciplines and channel more funds into the construction. Society must give as many opportunities as advice and criticism. Therefore, in order to develop the socialist market economy condition of high-quality composite English specialized talented person, the university English majors, ESP courses should with Needs analysis theory as the guide, adhering to the goal, needs sex, scientific, systematic and developmental principle, and these principles will throughout the process of course arrangement and teaching materials editing, teaching process and teaching evaluation so that the teaching always has more pertinence and effectiveness, and can better meet goals and students' learning needs. Researches mainly think the curriculum which can cultivate students' practical ability should be given priority to, and students' comprehensive quality of business English skills training should be paid more attention to, because it has great feasibility and matches the undergraduate employment needs.

\section{Conclusion}

This empirical investigation and analysis uses Needs Analysis to know students, whose major is English for International Trade (EFIT) in School of English for International Business (SEIB) in GDUFS, satisfactions and motivations in their current curriculum design. This issue has important and realistic meaning and value for study This study found problems including more than half of the students are not content with what they have learned in the four-year study, we lack of the opportunity to apply the professional knowledge to work outside the college, the teaching means are relatively simple and single and so on. In order to improve the situation, we should better balance the Business course and English course, adding more practical business skills training and internships. What's more, students and teachers should corporate with each other to create a better learning atmosphere but also verify the teaching methods and equipments. Last but not least, we should establish a highly anticipated Information feedback platform so that we can improve our curriculum all the time according to the students and society needs.

In this paper, only from the perspective of demand theory, only discuss Guangdong university of foreign studies business English college professional international trade in recent years curriculum problem, has certain 
limitations, research further verification.

\section{References}

Cook, V. (1993). Linguistics and Second Language Acquisition. London: Macmillan.

Dudley, W., Evans, T., \& St, John, M. J. (1998). Development in English for Specific Purposes. Cambridge: Cambridge University Press.

Ellis, M., \& Johnson, C. (1994). Teaching Business English. Oxford: Oxford University Press.

Mehdi Haseli Songhori. (2008). Introduction to Needs Analysis. English for Special Purposes world, 4, 2008. Retrieved from www.esp-would.info

Xie, E. R., \& An, F. Y. (2009). Analysis and Countermeasures on the Current Situation of the Business English Curriculum Design. Journal of Hubei University of Economics (Humanities and Social Sciences) (in Chinese), 6(5), 194-5.

Xu, X. Y. (2009). Needs Analysis and Business English Course Design. Journal of Sichuan College of Education (in Chinese), 25(9), 103-111.

Zhao, J. F. (2006). An Investigation into the Current Business English Curriculum Design and Instruction Practices in Colleges and Universities of China. China's Foreign Languages (in Chinese), 3(5), 9-12.

Zhou, R. Q. (2007). The Connotation and Curriculum Design of Business English. Journal of Qiqihar University (Phi \& Soc Sci) (in Chinese), 5, 154-6.

Pickett, D. (1989). The sleeping giant: Investigations in Business English. Language International, 1, 5-11.

Powell, M. Blur. (2005). 21st century Business English. Keynote Speech at the IATEFL BESIG STETS.

Robinson, P. (1991). ESP today: A practitioner's guide. Hemel Hempstead: Prentice-Hall.

Scollon, R., \& Scollon, S. W. (2001). Intercultural communication: A discourse approach (2nd ed.). Oxford: Blackwell Publishers Ltd. 